\title{
25. DOWNHOLE TEMPERATURE AND SHIPBOARD THERMAL CONDUCTIVITY MEASUREMENTS ABOARD D/V GLOMAR CHALLENGER IN THE RED SEA
}

\author{
Ron W. Girdler, School of Physics, The University, Newcastle upon Tyne , United Kingdom \\ and \\ Al J. Erickson and Richard Von Herzen, Woods Hole Oceanographic Institution, Woods Hole, Massachusetts
}

\begin{abstract}
Successful downhole temperature measurements were made at Sites 225,227 , and 228 , enabling reasonably good estimates of the temperature gradient at Sites 225 and 227 and a less reliable estimate at Site 228. In addition, an estimate of the minimum temperature gradient was obtained for Site 229 by measuring the temperatures of sediments in the core catchers.

On the cores of soft carbonate nanno oozes, 53 thermal conductivity measurements were made (18 for Site 225,12 for Site 227 , and 23 for Site 228). The mean of all the measurements is $1.315 \mathrm{Wm}^{-1} \mathrm{~K}^{-1}$.

The temperature gradients and conductivities enable the heat flow to be estimated at four of the six DSDP sites in the Red Sea. Heat flow values are all higher than the world mean, ranging from 105 to more than $251 \mathrm{mWm}^{-2}$.

These new measurements increase the total number of heat flow values for the Red Sea to 21. A new listing is given together with an updated map of heat flow values.
\end{abstract}

\section{INTRODUCTION}

During Leg 23, it was possible to obtain useful estimates of heat flow at four of the six sites drilled in the Red Sea. These increase the number of heat flow measurements in the Red Sea to 21. Previous work has been reviewed by Girdler (1970) who listed 12 measurements made with heat flow probes from survey ships and 5 estimates from temperature data taken in exploration boreholes. All but one of the 17 values show that the Red Sea has higher than normal heat flow. The axial, deep trough seems to have particularly high heat flow, the highest value being greater than $3306 \mathrm{mWm}^{-2}$ (Erickson and Simmons, 1969). The high heat flow also seems to extend over the margins, the values for the five exploration boreholes all being about twice the world mean.

Downhole temperatures were measured at Sites 225 (two values), 227 (four values), and 228 (three values) using a temperature probe designed at the Woods Hole Oceanographic Institution and described by Erickson (1973). It was not possible to obtain any measurements at Site 226 because of the early penetration of hard basalt. It also proved impossible to obtain temperature measurements at Sites 229 and 230 mainly because of bad weather (wind speeds of $50 \mathrm{mph}$ ). An attempt was made to obtain a measurement at 108 meters below bottom at Site 229, but the probe bent because of the presence of hard volcanic tuffs, and the recorder failed to switch on. The bumper subs became sanded up and further attempts to obtain measurements with the probe were abandoned. A minimum estimate of the heat flow was obtained at Site 229 by making crude measurements of the temperature of the material in the core catcher using a very simple thermometer as soon as the cores arrived on deck. Site 230 had to be abandoned prematurely because of bad weather so no temperature estimates were possible.

A total of 53 measurements of thermal conductivity of the soft sediments from Sites 225, 227, and 228 was made aboard the D/V Glomar Challenger using a needle-probe method. Measurements of thermal conductivities of the anhydrite and halite found beneath the soft sediments are described in an accompanying paper (Wheildon et al., this volume).

The measurements of down-hole temperatures and thermal conductivities aboard ship enabled reasonable estimates of the geothermal heat flux to be obtained for Sites 225, 227, and 228 and a very rough minimum estimate for Site 229 .

\section{DOWNHOLE TEMPERATURE MEASUREMENTS}

The temperature probe was generally lowered to the bottom of the drill string on the sand line during a pause in drilling operations. The instrument is designed such that a temperature measurement may be obtained at the same time as a core. On this leg, the heat flow probe was found to be too delicate to withstand the rigors of the coring operations, and it was altogether more satisfactory to make a separate operation of the heat flow measurement. This was economically feasible because of the relatively shallow water depths at the drill sites (less than $2 \mathrm{~km}$ ). 
A description of the instrument and its operation can be found in the DSDP Leg 19 Initial Report (Erickson, 1973). It is sufficient to mention here that the instrument has a probe containing a thermistor and a recording device which enables temperature to be recorded as a function of time while the thermistor probe is in the thermally undisturbed sediment at the bottom of the hole. The latter facility enables the quality of the data to be assessed for each downhole measurement.

In the following discussion of the downhole temperatures at the various sites, the temperature-time plots (Figures 1 to 3 ) are presented for each measurement. On the figures, temperature estimates are given to $0.01^{\circ} \mathrm{C}$ and in the text these are rounded to $0.1^{\circ} \mathrm{C}$. Errors are given in the text and are estimated from consideration of the temperature-time records and calibration uncertainties.

It is noted that the temperatures recorded with the downhole temperature probe for the bottom water $\left(22.3^{\circ}\right.$ to $22.4^{\circ} \mathrm{C}$ at Sites 225,227 , and 228 ) seem a little high. For example, Siedler (1969) gives temperatures of about $21.8^{\circ} \mathrm{C}$ for similar water depths. It is thought the discrepancy might be due to some confusion concerning the thermistor coefficients. As the other downhole temperatures would be similarly affected, the small discrepancy has a negligible effect on the estimates of the temperature gradients.

\section{Site 225}

Site 225 (latitude $21.31^{\circ} \mathrm{N}$, longitude $38.25^{\circ} \mathrm{E}$ ) has a water depth of 1228 meters, and downhole temperatures were obtained at 19 and 78 meters subbottom. An attempt to obtain a temperature measurement at 45 meters failed, the apparatus not switching on. The temperature-time plots for the two successful measurements are shown in Figure 1.

For the first measurement $(19 \mathrm{~m})$, the apparatus was switched on before penetrating the sediment to gain an idea of the full cycle of the operation. The graph shows the decrease in temperature as the probe is lowered down to the bottom of the drill string, a steady temperature near the bottom $\left(22.3 \pm 0.1^{\circ} \mathrm{C}\right)$, and then the increase in temperature as the probe is lowered into the sediment. The sediment temperature is read to be $24.2 \pm 0.1^{\circ} \mathrm{C}$.

For the measurement at 78 meters, the instrument switched on later giving a bottom temperature of $22.3 \pm$ $0.1^{\circ} \mathrm{C}$. A small portion of the record was lost, probably because of the unusually large accelerations during penetration due to rock fragments in the sediments. A maximum temperature of $29.2 \pm 0.2^{\circ} \mathrm{C}$ was recorded and this is taken to be the minimum temperature of the sediment, as the temperature curve suggests there was some slight disturbance after penetration.

The temperatures are plotted against subbottom depths in Figure 4 and lie on a straight line giving a thermal gradient of $92 \mathrm{~K} \mathrm{~km}^{-1}$.

\section{Site 227}

Site 227 (latitude $21.33^{\circ} \mathrm{N}$, longitude $28.13^{\circ} \mathrm{E}$ ) has a water depth of 1795 meters. Four downhole temperatures were obtained at $37,73,82$, and 159 meters. The temperature-time curves for these are shown in Figure 2.
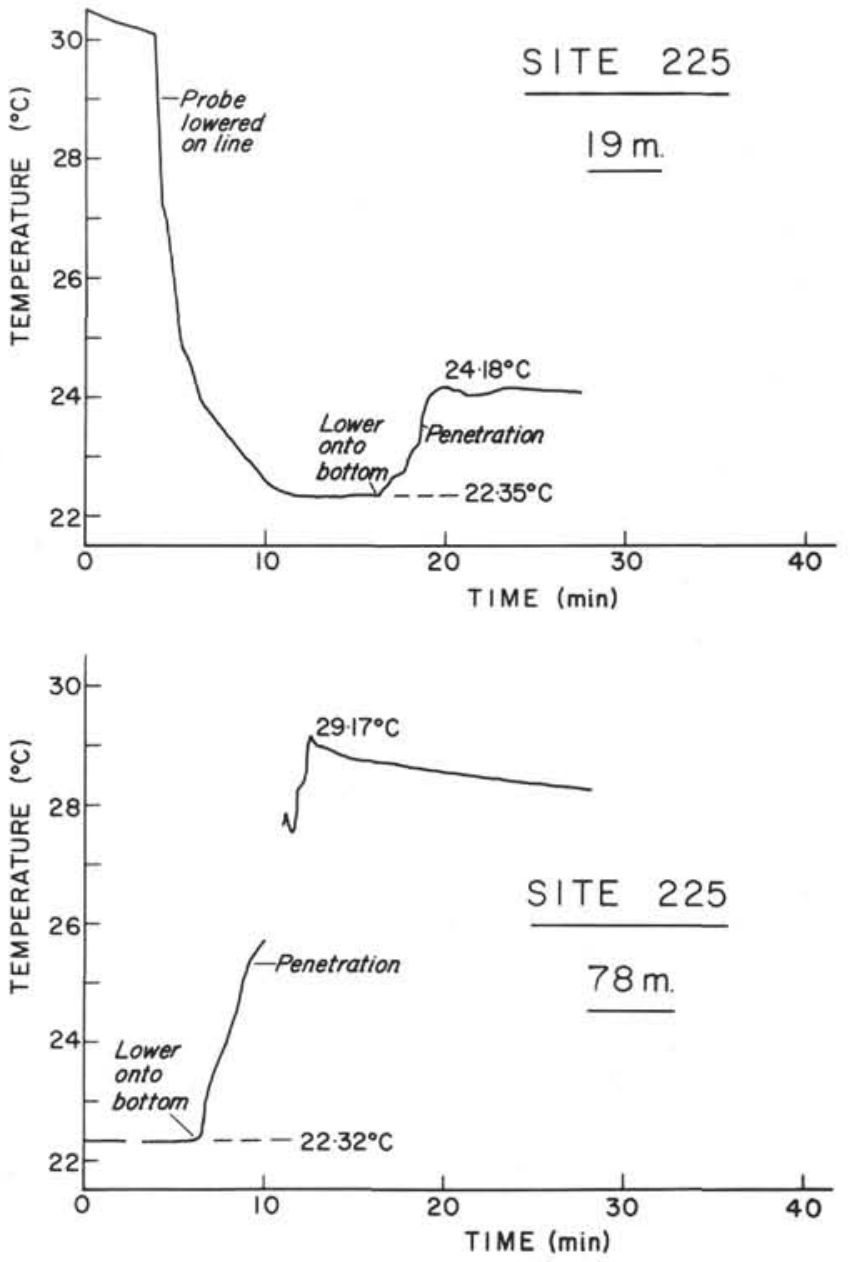

Figure 1. Temperature-time graphs for downhole temperatures recorded at subbottom depths of 19 and 78 meters at Site 225 .

Some difficulty was experienced with penetration of the probe due to the hardness of the bottom, the Master Core Inventory having descriptions such as "firm gray ooze" (36 $\mathrm{m})$, "stiff gray mud, slow coring" (72 m), and "hard mud" $(82 \mathrm{~m})$.

The temperature-time curve for the measurement at 37 meters illustrates this problem; the curve suggests the probe was disturbed and there are three possible temperatures to read. As there is little decay after reaching the highest value $\left(26.2 \pm 0.1^{\circ} \mathrm{C}\right)$ it seems that the probe finally penetrated relatively undisturbed sediment having previously recorded disturbed temperatures. It therefore seems logical to choose the highest reading.

The temperature-time curve for 73 meters shows that the equilibrium temperature of the sediment was not reached. It seems likely the probe was pushed up into the core barrel as evidenced by the sudden decrease in temperature after the maximum of $29.72^{\circ} \mathrm{C}$ was reached. The sediment temperature is therefore greater than $29.72^{\circ} \mathrm{C}$. Possible confirmation of this comes from the temperature subbottom depth plot in Figure 5 where it is seen that the temperature for 73 meters plots below the line joining the sea bottom and deeper downhole temperatures. 

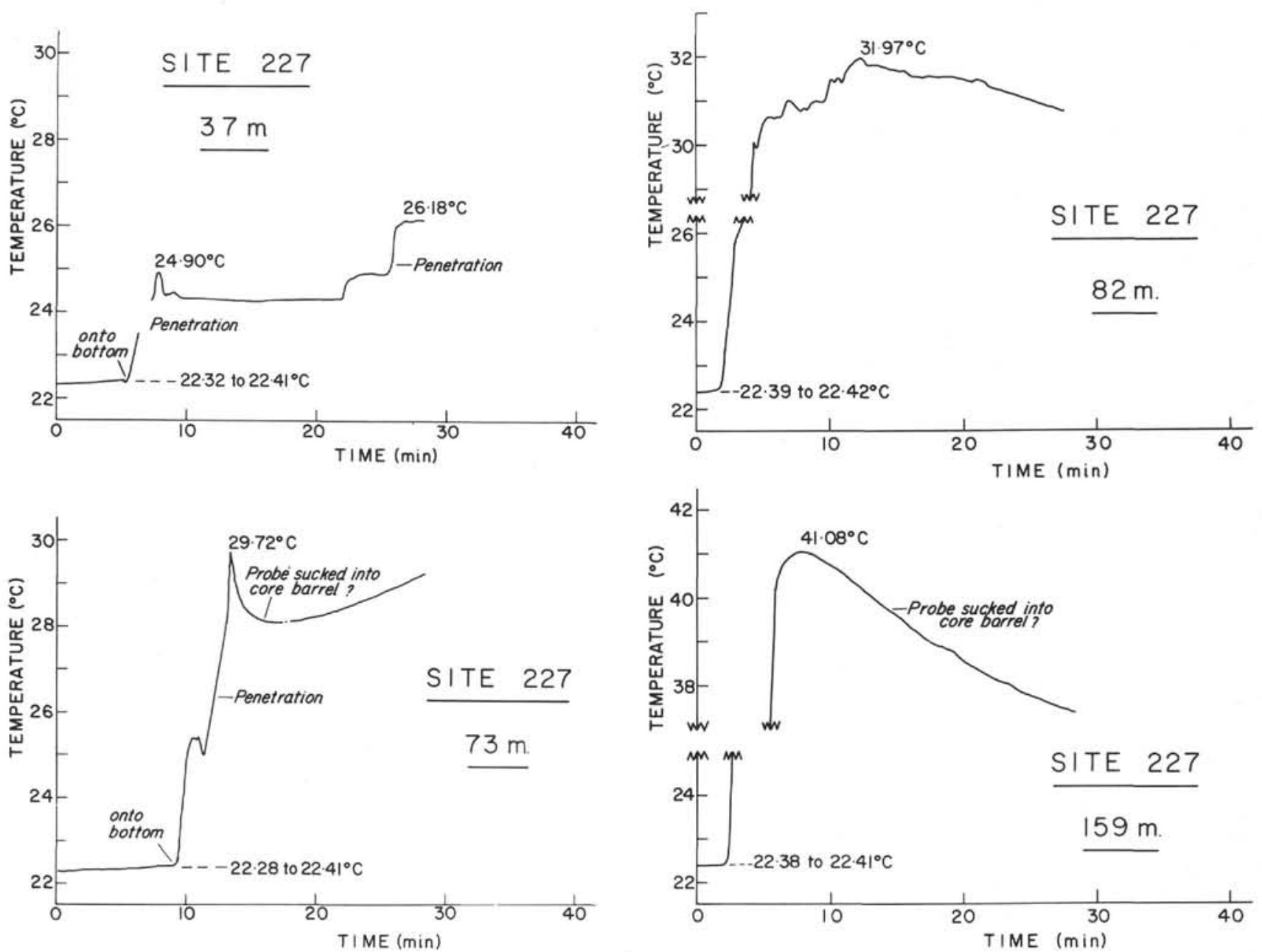

Figure 2. Temperature-time graphs for downhole temperatures recorded at subbottom depths of 37, 73, 82, and 159 meters at Site 227.

For the measurement at 82 meters, there is again evidence of movement of the probe after penetration but over much shorter time intervals than for the measurement at 37 meters. The slow general decrease of temperature after reaching a maximum of $31.97^{\circ} \mathrm{C}$ at 12.5 min suggests that both probe and sediment may have been pushed up into the core barrel. The in situ temperature is estimated as $32.0 \pm 0.2^{\circ} \mathrm{C}$.

In contrast to the other measurements, the probe easily penetrated for the final measurements at 159 meters. (A large part of the curve in Figure 2 is omitted, the ordinate scale being condensed because of the large temperature range.) The core is described as "fairly soupy" and the temperature increased rapidly by about $18.7^{\circ} \mathrm{C}$ as the probe penetrated. Unfortunately, the core and instrument were probably pushed up into the core barrel as evidenced by the fairly rapid decrease in temperature. The maximum temperature recorded was $41.08^{\circ} \mathrm{C}$, and the in situ temperature is estimated to be $41.1 \pm 0.2^{\circ} \mathrm{C}$.

The temperatures are plotted against subbottom depths in Figure 5. Considering the difficulties experienced at this site, it is somewhat reassuring that the temperature lie so nicely on a straight line giving a thermal gradient of 117 $\mathrm{K} \mathrm{km-1.}$
Site 228

At Site 228 (latitude $19.09^{\circ} \mathrm{N}$, longitude $39.00^{\circ} \mathrm{E}$ ), the water depth is 1038 meters, and downhole temperatures were obtained at 25,61 , and 97 meters subbottom. The temperature-time graphs are shown in Figure 3.

The first measurement at 25 meters was made in soft carbonate ooze, and a good temperature-time graph was obtained giving a temperature of $24.7 \pm 0.1^{\circ} \mathrm{C}$.

The temperature-time curve for the second measurement at 61 meters shows the probe was disturbed, there being a sharp temperature decrease after the maximum of $26.67^{\circ} \mathrm{C}$ was reached. The disturbance suggests that the in situ temperature of the sediments was not measured at this depth.

The next measurement at 97 meters subbottom was in hard mud. The temperature-time curve shows a large increase in temperature from $22.25^{\circ} \mathrm{C}$ to $40.33^{\circ} \mathrm{C}$, suggesting the probe successfully penetrated the sediment. The temperature then decreased, first slowly and then very sharply after $13.3 \mathrm{~min}$, suggesting the probe possibly rose back into the core barrel and then separated from the sediment. The in situ temperature is estimated at $40.4 \pm$ $0.2^{\circ} \mathrm{C}$. 

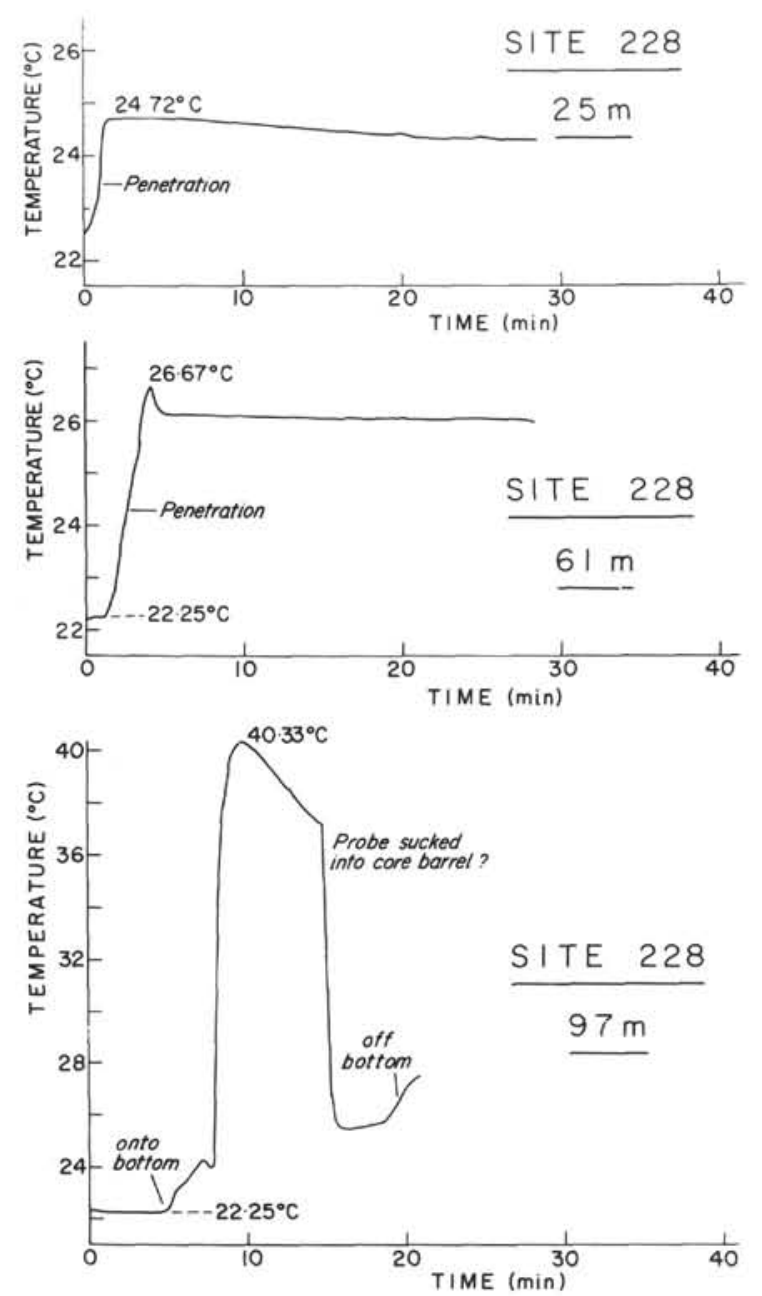

Figure 3. Temperature-time graphs for downhole temperatures recorded at subbottom depths of 25, 61, and 97 meters at Site 228.

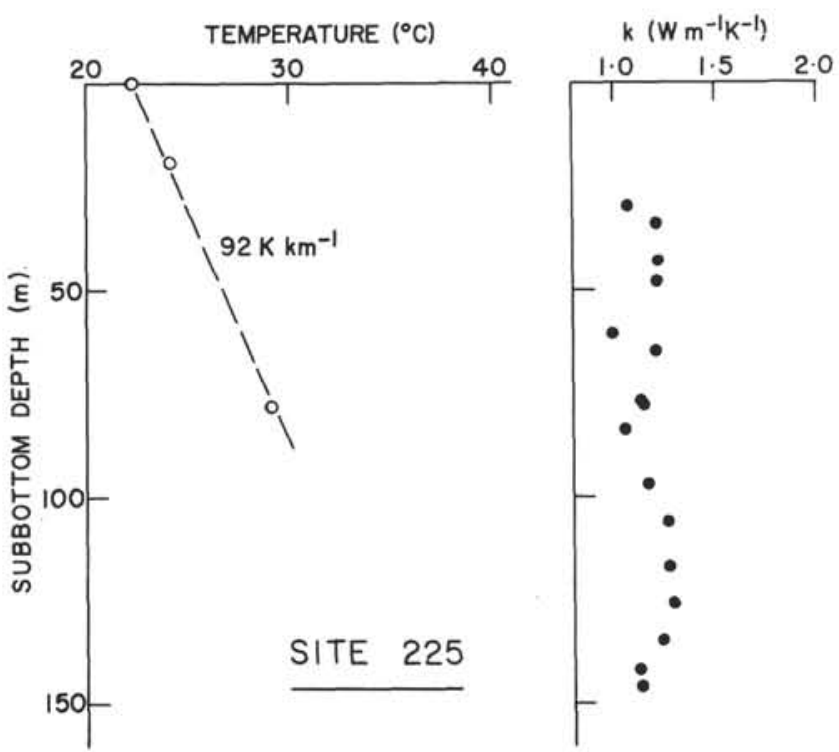

Figure 4. Temperatures plotted against subbottom depths for Site 225 together with thermal conductivities over the depth range of the temperature measurements.

Three further attempts at measuring temperatures at this site (subbottom depths of 133,174 , and 228 meters) failed

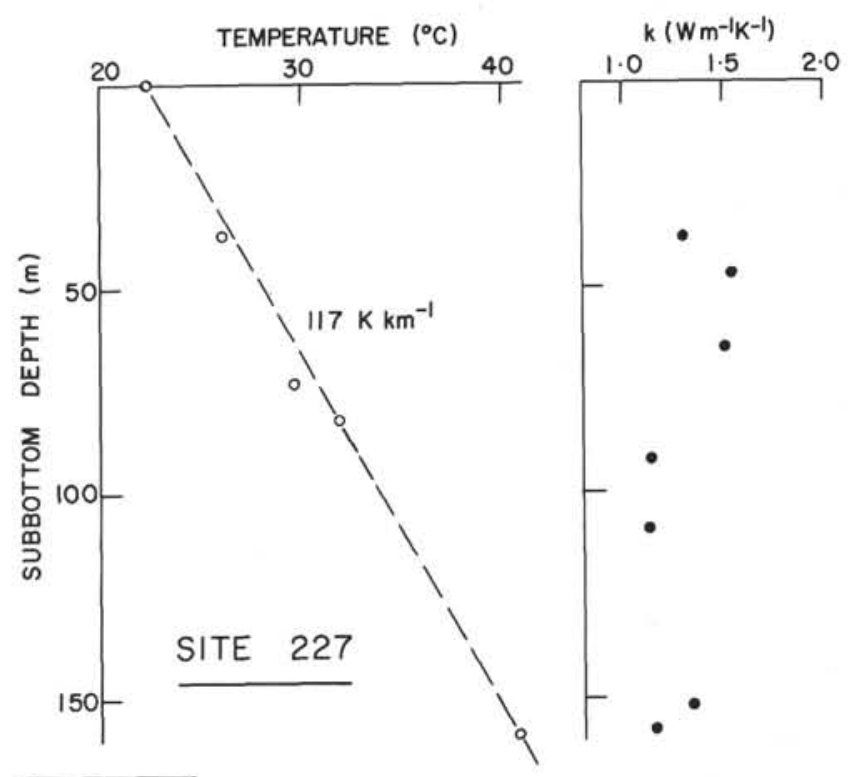

Figure 5. Temperatures plotted against subbottom depths for Site 227 together with thermal conductivities over the depth range of the temperature measurements.

due to malfunctioning of the apparatus. This was most unfortunate as it is seen from the temperature-depth plot (Figure 6) that, unlike for the previous sites, the points do not lie on a line, and the data do not seem sufficiently unambiguous to exclude the possibility of nonlinear gradients due to possible hydrothermal circulations at this site. The best that can be done is to accept the maximum temperature gradient $\left(186 \mathrm{~K} \mathrm{~km}^{-1}\right)$ obtained by taking the bottom water temperature and the maximum temperature of $40.4^{\circ} \mathrm{C}$ obtained at 97 meters subbottom depth. As expected from the temperature-time curve, the temperature for 61 meters plots below this line confirming that the probe was disturbed. It is noted that the gradient is the highest recorded for all the sites.

Site 229

As mentioned in the introduction, it was hazardous to use the downhole temperature probe at Site 229 (latitude $14.77^{\circ} \mathrm{N}$, longitude $42.19^{\circ} \mathrm{E}$ ) because of the adverse weather conditions and the shallow water depth of 852 meters. The one attempt to use the probe at a subbottom depth of 109 meters failed, the probe becoming bent possibly due to the presence of hard volcanic tuffs (the site is near Zebayir Island). It was noticed that the sediment in the core catcher felt warm to the touch; therefore, three temperature measurements were made by inserting a crude thermometer into the core catcher sediment as soon as the cores arrived on deck. These gave temperatures of $29^{\circ} \mathrm{C}$ at 74 meters, $28^{\circ} \mathrm{C}$ at 83 meters, and $39^{\circ} \mathrm{C}$ at 212 meters subbottom depths. These temperatures are plotted against subbottom depths in Figure 7 and give reasonable gradients. It is probably safe to conclude that the minimum temperature gradient at Site 229 is $99 \mathrm{~K} \mathrm{~km}^{-1}$.

\section{THERMAL CONDUCTIVITIES}

Thermal conductivities of the soft sediments from Sites 225,227 , and 228 were measured aboard D/V Glomar Challenger using the needle-probe method (Von Herzen and 


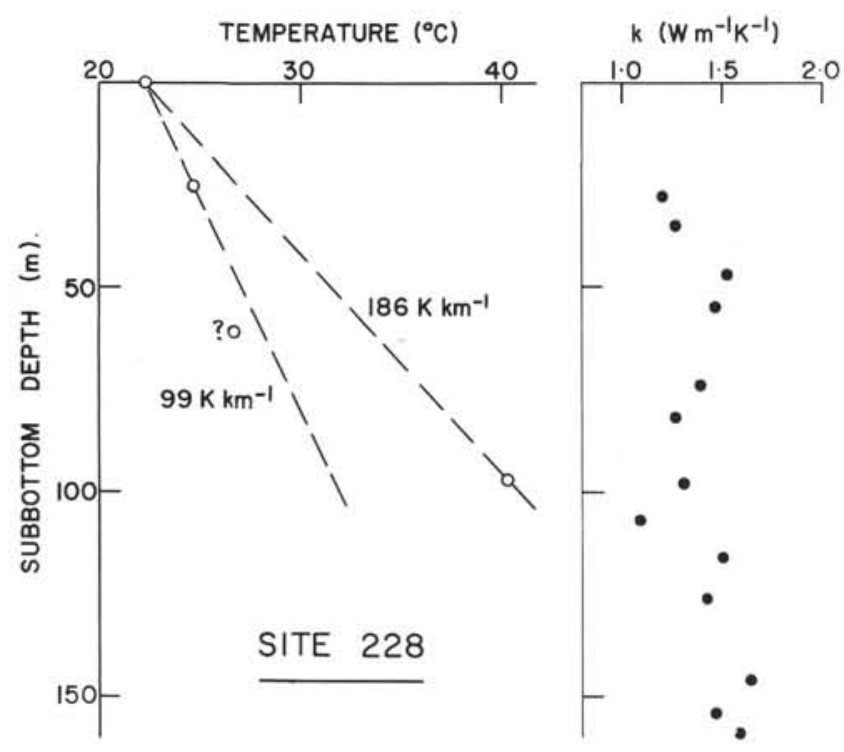

Figure 6. Temperatures plotted against subbottom depths for Site 228 together with thermal conductivities over the depth range of the temperature measurements.

Maxwell, 1959). The cores from the other sites proved unsuitable-Site 226 cores yielding igneous rocks, cores from Site 229 having a high gas content, and Site 230 cores yeilding only one and a half core barrels of disturbed sediment.

Strip-chart recordings of needle-probe temperature versus time were digitized and the times and temperatures fitted to a curve of the form

$$
T=A+B t+C \ln (t)
$$

where $T$ is the temperature, $t$ is the time, and $A, B, C$ are coefficients determined using a nonlinear regression program.

These computed values are for the pressure and temperature conditions of the laboratory, and it is necessary to convert these to the conditions at the appropriate depth in the drill hole. This is done using the correction factors given by Ratcliffe (1960) and modified for use in drill holes by Erickson (1973). The relationship is:

$$
\begin{gathered}
\begin{array}{l}
\text { Corrected } \\
\text { Conductivity }
\end{array}=\begin{array}{l}
\text { Measured } \\
\text { Conductivity }
\end{array} \quad \mathrm{X} \\
{\left[1+\left(\frac{W+\rho H}{182900}\right)+\left(\frac{T_{w}+\frac{d t}{d z}-T_{1 \mathrm{ab}}}{400}\right)\right]}
\end{gathered}
$$

where

$$
\begin{array}{ll}
W & =\text { water depth }(\mathrm{m}) \\
\rho & =\text { mean sediment density }\left(\mathrm{g} / \mathrm{cm}^{3}\right) \\
H & =\text { drill hole depth }(\mathrm{m}) \\
T_{W} & =\text { bottom water temperature }\left({ }^{\circ} \mathrm{C}\right) \\
d t / d z & =\text { mean geothermal gradient }\left({ }^{\circ} \mathrm{Cm}^{-1}\right) \\
T_{1 \mathrm{ab}} & =\text { laboratory ambient sediment temperature }\left({ }^{\circ} \mathrm{C}\right)
\end{array}
$$

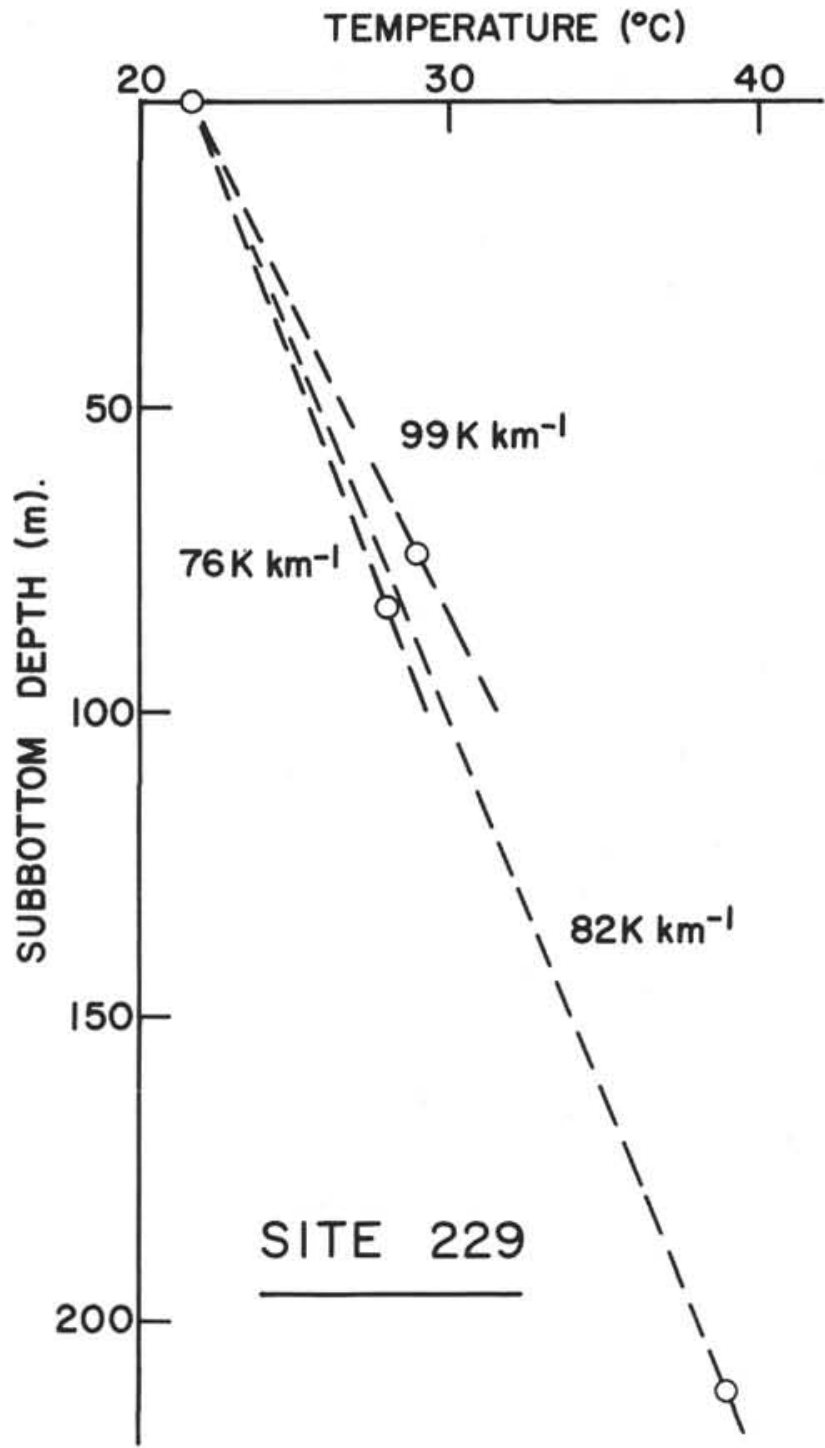

Figure 7. Crude temperature measurements of the material in the core catcher giving minimum estimates for the temperature gradient at Site 229.

The parameters used for Sites 225,227 , and 228 are given in Table 1 . The environmental corrections are only a few percent and uncertainties in these parameters are negligible for most purposes.

The environmentally corrected conductivities for the three sites $(225,227$, and 228) are shown plotted as a function of depth in Figure 8, and numerical listings of both uncorrected and corrected values are given in Tables 2 , 3 , and 4 .

The description of the lithologies are for Site 225, "detrital clayey silt rich carbonate nanno ooze and chalk"; for Site 227, "carbonate nanno ooze and chalk"; and for Site 228 , "silty nanno-foram carbonate ooze and chalk and calcareous siltstone." The ages range back into the early Pliocene. It is seen from Figure 8 that the thermal conductivities for Site 225 show much less scatter than for Sites 227 and 228 suggesting the sediments are more homogeneous at Site 225. For Site 228 the thermal 
THERMAL CONDUCTIVITY $\left(\mathrm{W} \mathrm{m}^{-1} \mathrm{~K}^{-1}\right)$
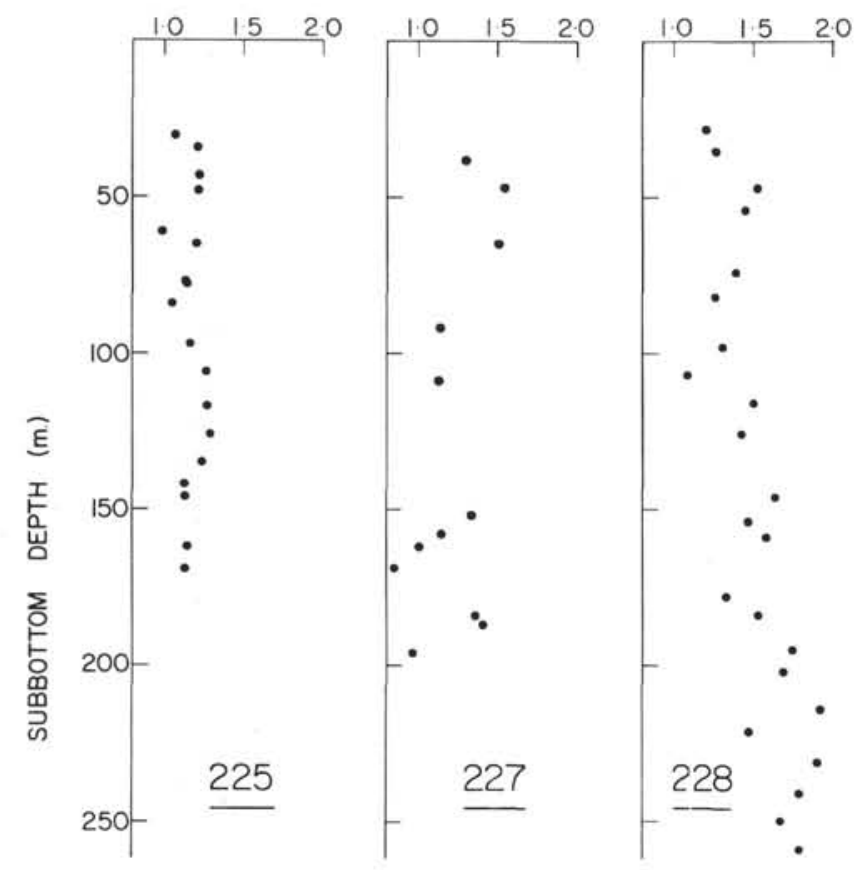

Figure 8. Thermal conductivities plotted against subbottom depths for Sites 225, 227, and 228.

TABLE 1

Site Parameters for Environmental Corrections

\begin{tabular}{ccccc}
\hline Site & $\begin{array}{c}\text { Water } \\
\text { Depth } \\
(\mathrm{m})\end{array}$ & $\begin{array}{c}\text { Water } \\
\text { Temperature } \\
\left({ }^{\circ} \mathrm{C}\right)\end{array}$ & $\begin{array}{c}\text { Geothermal } \\
\text { Gradient } \\
\left({ }^{\circ} \mathrm{C} / \mathrm{m}\right)\end{array}$ & $\begin{array}{c}\text { Sediment } \\
\text { Density } \\
\left(\mathrm{g} / \mathrm{cm}^{3}\right)\end{array}$ \\
\hline 225 & 1228 & 21.6 & 0.089 & 1.8 \\
227 & 1795 & 21.6 & 0.118 & 1.9 \\
228 & 1038 & 21.6 & 0.186 & 1.9 \\
\hline
\end{tabular}

conductivities are somewhat higher, and the plot shows a tendency for the conductivity to increase with depth. The mean conductivities (with standard deviations) for the three sites are given in Table 5.

\section{HEAT FLOW}

With the above experimental data, estimates can be obtained for the heat flow at Sites 225, 227, 228, and 229. As the heat flow is the temperature gradient multiplied by the thermal conductivity, these are shown together in Figures 4, 5, and 6 for Sites 225, 227, and 228, respectively. Figure 7 shows the estimates of the minimum temperature gradients for Site 229; no thermal conductivity measurements are available due to the degassing of the cores from this site.

The values of the temperature gradients and conductivities used to determine the heat flow at the four sites are listed in Table 6. It is somewhat difficult to assign realistic estimates of the errors associated with these values. The estimates for the four sites are discussed in turn.

For Site 225 (Figure 4) the temperature gradient is estimated as $92 \pm 4 \mathrm{~K} \mathrm{~km}^{-1}$, but it is noted that this depends on only three measurements. The thermal conductivity for the depth range corresponding to the tempera-
TABLE 2

Thermal Conductivities for Site $\mathbf{2 2 5}$

\begin{tabular}{|c|c|c|c|c|c|}
\hline Core & Section & $\begin{array}{l}\text { Position } \\
\text { (cm) }\end{array}$ & $\begin{array}{l}\text { Subbottom } \\
\text { Depth } \\
\text { (m) }\end{array}$ & $\begin{array}{c}\text { Measured } \\
\text { Conductivity } \\
\left(\mathrm{Wm}^{-1} \mathrm{~K}^{-1}\right)\end{array}$ & $\begin{array}{c}\text { Corrected } \\
\text { Conductivity } \\
\left(\mathrm{Wm}^{-1} \mathrm{~K}^{-1}\right)\end{array}$ \\
\hline 4 & 5 & 100 & 30 & 1.064 & 1.074 \\
\hline 5 & 5 & 100 & 34 & 1.214 & 1.217 \\
\hline 6 & 5 & 80 & 43 & 1.211 & 1.222 \\
\hline 8 & 2 & 100 & 48 & 1.211 & 1.218 \\
\hline 9 & 5 & 80 & 61 & 0.980 & 0.993 \\
\hline 10 & 2 & 80 & 65 & 1.189 & 1.203 \\
\hline 11 & 5 & 40 & 78 & 1.123 & 1.143 \\
\hline 12 & 1 & 80 & 77 & 1.117 & 1.138 \\
\hline 13 & 5 & 75 & 84 & 1.038 & 1.058 \\
\hline 15 & 2 & 77 & 97 & 1.143 & 1.170 \\
\hline 16 & 2 & 77 & 106 & 1.231 & 1.262 \\
\hline 17 & 3 & 78 & 117 & 1.238 & 1.272 \\
\hline 18 & 3 & 68 & 126 & 1.261 & 1.295 \\
\hline 19 & 3 & 68 & 135 & 1.200 & 1.239 \\
\hline 20 & 2 & 78 & 142 & 1.087 & 1.123 \\
\hline 21 & 2 & 101 & 146 & 1.097 & 1.135 \\
\hline 22 & 3 & 65 & 162 & 1.105 & 1.145 \\
\hline 23 & 2 & 60 & 169 & 1.097 & 1.135 \\
\hline
\end{tabular}

TABLE 3

Thermal Conductivities for Site 227

\begin{tabular}{rcrccc}
\hline Core & Section & $\begin{array}{c}\text { Position } \\
(\mathrm{cm})\end{array}$ & $\begin{array}{c}\text { Subbottom } \\
\text { Depth } \\
(\mathrm{m})\end{array}$ & $\begin{array}{c}\text { Measured } \\
\text { Conductivity } \\
\left(\mathrm{Wm}^{-1} \mathrm{~K}^{-1}\right)\end{array}$ & $\begin{array}{c}\text { Corrected } \\
\text { Conductivity } \\
\left(\mathrm{Wm}^{-1} \mathrm{~K}^{-1}\right)\end{array}$ \\
\hline 2 & 2 & 80 & 38 & 1.281 & 1.301 \\
6 & 1 & 150 & 47 & 1.517 & 1.551 \\
8 & 1 & 150 & 65 & 1.466 & 1.509 \\
13 & 2 & 81 & 92 & 1.108 & 1.140 \\
15 & 1 & 105 & 109 & 1.098 & 1.136 \\
20 & 3 & 47 & 152 & 1.280 & 1.341 \\
21 & 4 & 77 & 158 & 1.153 & 1.156 \\
22 & 3 & 73 & 162 & 1.003 & 1.005 \\
23 & 1 & 140 & 169 & 0.849 & 0.852 \\
24 & 6 & 95 & 184 & 1.285 & 1.364 \\
25 & 2 & 90 & 187 & 1.335 & 1.415 \\
26 & 2 & 80 & 196 & 0.907 & 0.965 \\
\hline
\end{tabular}

tures is taken as the mean of the top 10 measurements giving $1.144 \pm 0.075 \mathrm{Wm}^{-1} \mathrm{~K}^{-1}$, i.e., somewhat less than the mean value of $1.171 \pm 0.079 \mathrm{Wm}^{-1} \mathrm{~K}^{-1}$ for all the values from Site 228 (Table 5). The heat flow is thus $105 \pm 11$ $\mathrm{mWm}^{-2}$.

For Site 227 (Figure 5) the temperature gradient is estimated as $117 \pm 8 \mathrm{~K} \mathrm{~km}^{-1}$; this is slightly weighted in favor of the higher values (cf. the straight line drawn in Figure 5). There are seven thermal conductivity measurements over the 160-meter depth range of the temperature measurements and these give a mean of $1.305 \pm 0.161$ $\mathrm{Wm}^{-1} \mathrm{~K}^{-1}$. The heat flow is thus $153 \pm 29 \mathrm{mWm}^{-2}$, the experimental error of just less than $\pm 20 \%$ is considered reasonable and acceptable.

For Site 228 there is the problem of the choice of temperature gradient as evidenced by the temperaturesubbottom depth graphs in Figure 6. Following the discussion in the section on downhole temperature measurements, the higher gradient is chosen as the most likely. The thermal conductivity over the depth range of the measurements is taken as $1.348 \pm 0.108 \mathrm{Wm}^{-1} \mathrm{~K}^{-1}$. 
TABLE 4

Thermal Conductivities for Site 228

\begin{tabular}{|c|c|c|c|c|c|}
\hline Core & Section & $\begin{array}{l}\text { Position } \\
\quad(\mathrm{cm})\end{array}$ & $\begin{array}{l}\text { Subbottom } \\
\text { Depth } \\
\text { (m) }\end{array}$ & $\begin{array}{c}\text { Measured } \\
\text { Conductivity } \\
\left(\mathrm{Wm}^{-1} \mathrm{~K}^{-1}\right)\end{array}$ & $\begin{array}{c}\text { Corrected } \\
\text { Conductivity } \\
\left(\mathrm{Wm}^{-1} \mathrm{~K}^{-1}\right)\end{array}$ \\
\hline 4 & 3 & 79 & 28 & 1.194 & 1.208 \\
\hline 5 & 2 & 78 & 35 & 1.252 & 1.272 \\
\hline 6 & 4 & 85 & 47 & 1.491 & 1.523 \\
\hline 7 & 2 & 83 & 54 & - & - \\
\hline 10 & 4 & 0 & 74 & 1.387 & 1.395 \\
\hline 11 & 3 & 77 & 82 & 1.213 & 1.261 \\
\hline 13 & 2 & 0 & 98 & 1.310 & 1.306 \\
\hline 14 & 2 & 78 & 107 & 1.035 & 1.089 \\
\hline 15 & 2 & 72 & 116 & 1.427 & 1.503 \\
\hline 16 & 2 & 76 & 126 & 1.349 & 1.425 \\
\hline 18 & 2 & 77 & 146 & 1.543 & 1.641 \\
\hline 19 & 3 & 77 & 154 & 1.380 & 1.464 \\
\hline 20 & 3 & 76 & 159 & 1.488 & 1.584 \\
\hline 22 & 4 & 70 & 178 & 1.240 & 1.337 \\
\hline 23 & 2 & 79 & 184 & 1.443 & 1.536 \\
\hline 24 & 3 & 55 & 195 & 1.608 & 1.753 \\
\hline 25 & 2 & 93 & 202 & 1.539 & 1.691 \\
\hline 26 & 4 & 49 & 214 & 1.740 & 1.925 \\
\hline 27 & 2 & 105 & 221 & 1.329 & 1.479 \\
\hline 28 & 4 & 38 & 232 & 1.708 & 1.905 \\
\hline 29 & 4 & 65 & 241 & 1.608 & 1.792 \\
\hline 30 & 4 & 74 & 250 & 1.491 & 1.668 \\
\hline 31 & 4 & 65 & 259 & 1.592 & 1.788 \\
\hline
\end{tabular}

TABLE 5

Site Mean Thermal

Conductivities

\begin{tabular}{cc}
\hline Site & $\begin{array}{c}\text { Conductivities } \\
\left(\mathrm{Wm}^{-1} \mathrm{~K}^{-1}\right)\end{array}$ \\
\hline 225 & $1.171 \pm 0.079(\underline{\mathrm{N}}=18)$ \\
227 & $1.252 \pm 0.205(\underline{\mathrm{N}}=12)$ \\
228 & $1.522 \pm 0.219(\underline{\mathrm{N}}=23)$ \\
\hline
\end{tabular}

These values give a somewhat questionable heat flow of 251 $\mathrm{mWm}^{-2}$. It is not realistic to quote an experimental error on this value because of the difficulty with the temperature gradient.

For Site 229, only the rough minimum temperature estimates are available. From Figure 8, it is reasonable to assume that the temperature gradient is greater than $100 \mathrm{~K}$ $\mathrm{km}^{-1}$. As there are no thermal conductivity measurements for this site, the mean thermal conductivity of $1.266 \mathrm{Wm}^{-1}$ $\mathrm{K}^{-1}$ for Sites 225,227 , and 228 calculated from the values in Table 6 is assumed. The heat flow at Site 229 is thus greater than $127 \mathrm{mWm}^{-2}$.

The heat flow results are summarized in Table 6 .

TABLE 6

Heat Flow for Red Sea Deep Sea Drilling Sites

\begin{tabular}{cccc}
\hline Site & $\begin{array}{c}\text { Temperature } \\
\text { Gradient } \\
\left(\mathrm{K} \mathrm{km}^{-1}\right)\end{array}$ & $\begin{array}{c}\text { Conductivity } \\
\left(\mathrm{Wm}^{-1} \mathrm{~K}^{-1}\right)\end{array}$ & $\begin{array}{c}\text { Heat Flow } \\
\left(\mathrm{mWm}^{-2}\right)\end{array}$ \\
\hline 225 & $92 \pm 4$ & $1.144 \pm 0.075$ & $105 \pm 11$ \\
227 & $117 \pm 8$ & $1.305 \pm 0.161$ & $153 \pm 29$ \\
228 & $? 186$ & $1.348 \pm 0.108$ & $? 251$ \\
229 & $>100$ & 1.266 & $>127$ \\
\hline
\end{tabular}

\section{DISCUSSION AND CONCLUSIONS}

It is seen from Table 6 that the heat flow for all the Red Sea drilling sites is considerably higher than the world mean of $63 \mathrm{mWm}^{-2}$. The value for Site 225 is about 1.7 times; for Site 227, about 2.4 times; for Site 228, about 4 times; and for Site 229, at least 2 times the world mean. This pattern is consistent with previous heat flow measurements in the Red Sea listed by Girdler (1970). The list is updated to include the D/V Glomar Challenger sites in Table 7, while Figure 9 shows a map of all the Red Sea heat flow values (complete to the end of 1972). The D/V Glomar Challenger sites are marked with solid circles. Perhaps the most interesting result is Site $229\left(>127 \mathrm{mWm}^{-2}\right)$ which shows for the first time that high heat flow is observed in the southern part of the Red Sea (south of $15^{\circ} \mathrm{N}$ ). It is seen that the other results also conform to the pattern of the highest values being near the central axis of the Red Sea. It may be safely concluded that in spite of the various difficulties, the heat flow at four of the six D/V Glomar Challenger drilling sites in the Red Sea is appreciably higher than normal.

The significance of such results has been discussed by Girdler (1970). It is sufficient to mention here that the high heat flow is probably associated with a widening intrusive zone down the central axis of the Red Sea associated with the movement apart of Arabia and Nubia and consequent sea floor spreading.

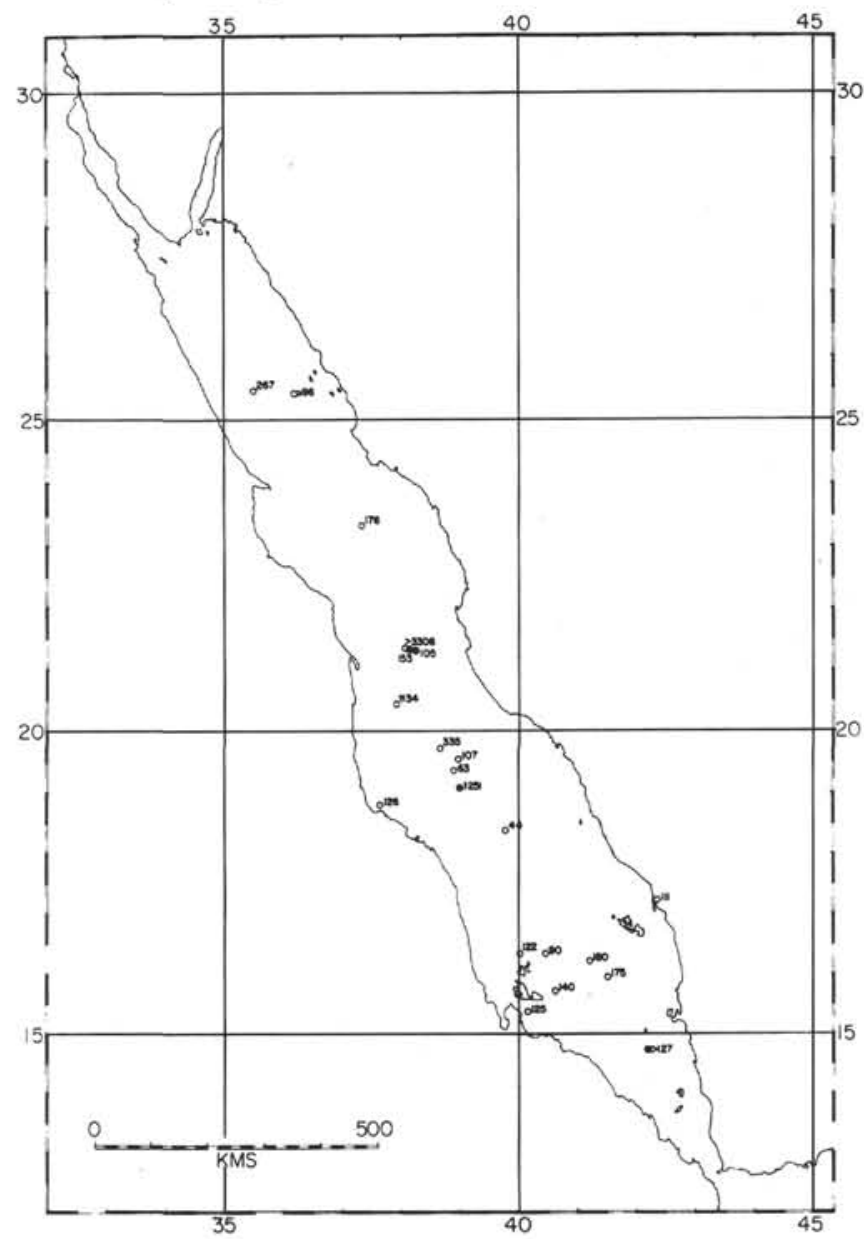

Figure 9. Heat flow map of the Red Sea from Girdler (1970) updated to include the Glomar Challenger measurements. 
TABLE 7

Red Sea Heat Flow Measurements

\begin{tabular}{lcccrl}
\hline $\begin{array}{c}\text { Station } \\
\text { or Well } \\
\text { Designation }\end{array}$ & $\begin{array}{c}\text { Latitude } \\
\left({ }^{\circ} \mathrm{N}\right)\end{array}$ & $\begin{array}{c}\text { Longitude } \\
\left({ }^{\circ} \mathrm{E}\right)\end{array}$ & $\begin{array}{c}\text { Water } \\
\text { Depth } \\
(\mathrm{km})\end{array}$ & $\begin{array}{c}\text { Heat Flow } \\
\left(\mathrm{mWm}^{-2}\right)\end{array}$ & \multicolumn{1}{c}{ Reference } \\
\hline Co 9-113 & 25.47 & 35.49 & 1.335 & 267 & Langseth and Taylor (1967) \\
CH 43-24 & 25.40 & 36.17 & 2.205 & $\geqslant 96$ & Birch and Halunen (1966) \\
CH 61-167 & 23.33 & 37.33 & 0.826 & 176 & Erickson and Simmons (1969) \\
CH 61 & 21.37 & 38.08 & 2.0 & $>3306$ & Erickson and Simmons (1969) \\
DSDP 227 & 21.33 & 38.13 & 1.795 & 153 & This paper \\
DSDP 225 & 21.31 & 38.25 & 1.228 & 105 & This paper \\
5234 & 20.45 & 37.92 & 0.870 & $? 134$ & Sclater (1966) \\
CH 61-153 & 19.72 & 38.68 & 2.704 & 335 & Erickson and Simmons (1969) \\
CH 61-154 & 19.57 & 38.98 & 1.276 & 107 & Erickson and Simmons (1969) \\
CH 61-155 & 19.38 & 38.90 & 2.207 & 63 & Erickson and Simmons (1969) \\
DSDP 228 & 19.09 & 39.00 & 1.038 & $? 251$ & This paper \\
Durwara 1,2 & 18.81 & 37.64 & Shelf & 126 & Girdler (1970) \\
5232 & 18.40 & 39.78 & 1.480 & 44 & Sclater (1966) \\
Mansiyah 1 & 17.22 & 42.37 & Shelf & 111 & Girdler (1970) \\
Amber 1 & 16.35 & 40.01 & Shelf & 122 & Girdler (1970) \\
Co 9-112 & 16.34 & 40.47 & 1.223 & 90 & Langseth and Taylor (1967) \\
Co 9-111 & 16.22 & 41.21 & 0.941 & 180 & Langseth and Taylor (1967) \\
5231 & 15.97 & 41.52 & 1.735 & 175 & Sclater (1966) \\
Dhunishub 1 & 15.72 & 40.62 & Shelf & 140 & Girdler (1970) \\
Secca Fawn 1 & 15.39 & 40.16 & Shelf & 125 & Girdler (1970) \\
DSDP 229 & 14.77 & 42.19 & 0.852 & $>127$ & This paper \\
\hline
\end{tabular}

\section{ACKNOWLEDGMENTS}

We are most grateful to Lloyd Russill and Kirk van Allyn (electronics technicians) for invaluable help aboard the D/V Glomar Challenger and to Jane Dunworth (computer assistant at Woods Hole Oceanographic Institution) for digitizing records and computing the thermal conductivities. The development of instruments for this project is supported by National Science Foundation Grant GA 28504 .

\section{REFERENCES}

Birch, F. S. and Halunen, A. J., 1966. Heat flow measurements in the Atlantic Ocean, Indian Ocean, Mediterranean Sea and Red Sea. J. Geophys. Res., v. 71, p. 583-586.

Erickson, A., 1973. Initial report on downhole temperature and shipboard conductivity measurements, Leg 19, the Deep Sea Drilling Project. In Creager, J. S., Scholl, D. W., et al., Volume XIX: Washington (U. S. Government Printing Office), p. 643.
Erickson, A. and Simmons, G., 1969. Thermal measurements in the Red Sea hot brine pools. In Hot brines and recent heavy metal deposits in the Red Sea: Degens, E. T. and Ross, D. A. (Eds.), New York (SpringerVerlag), p. 114-121.

Girdler, R. W., 1970. A review of Red Sea heat flow: Phil. Trans. Roy. Soc. Lond., A., v. 267, p. 191-203.

Langseth, M. G. and Taylor, P. T., 1967. Recent heat flow measurements in the Indian Ocean. J. Geophys. Res., v. 72 , p. $6249-6260$.

Ratcliffe, E. H., 1960. The thermal conductivities of ocean sediments. J. Geophys. Res., v. 65, p. 1535-1541.

Sclater, J. G., 1966. Heat flow in the north west Indian Ocean and Red Sea. Phil. Trans. Roy. Soc. Lond., A., v. 259, p. 271-278.

Siedler, G., 1969. General Corculation of Water Masses in the Red Sea. In Hot brines and recent heavy metal deposits in the Red Sea: Degens, E. T. and Ross, D. A. (Eds.), New York (Springer-Verlag), p. 131-137.

Von Herzen, R. and Maxwell, A. E., 1959. The measurement of thermal conductivity of deep-sea sediments by a needle-probe method. J. Geophys. Res., v. 64, p. 1557-1563. 